\title{
Produktivitas Kambing Lokal dengan Pemberian Urea Molasses Block (UMB) di Kabupaten Bintan, Provinsi Kepulauan Riau
}

\section{(The Productivity of Local Goat Fed with Urea Molasses Block in Bintan Regency, Riau Islands Province)}

\author{
Zurriyati Y \\ Loka Pengkajian Teknologi Pertanian Kepulauan Riau \\ Jl. Pelabuhan Sungai Jang No. 27, Tanjung Pinang, Kepulauan Riau \\ yayuzurriyati@yahoo.co.id
}

\begin{abstract}
Supplementary feeding is useful to optimize goat production. The research was conducted in the Tembeling Village, Bintan regency, Riau Island Province, to determine body weight gain of local goat fed with urea molasses block (UMB) supplement. The Goats belongs to farmer cooperators were 30 females (age 8-10 months) and six males (age \pm 10 months), was divided into three group of ten female and two male goat for each treatment. Three feeding treatments were used in the experiment, consisted of $\mathrm{A}=$ Grass + UMB I; $\mathrm{B}=$ Grass+UMB II; and C = Control/ grass only. Parameters measured was daily body weight gain of goats during four month and were subjected to the analysis of variance (ANOVA). The study showed that daily weight gain for females are significantly $(\mathrm{P}<0.05)$ higher for goat receiving treatment $\mathrm{A}(35.9 \mathrm{~g} / \mathrm{head} / \mathrm{day})$ compared to control goats $(32.1 \mathrm{~g} / \mathrm{head} / \mathrm{day})$. Whereas males did not significantly difference in daily weight gain with were 35.4-38.4 g/head/day. Generally, the daily weight gain of female goats receiving UMB I were higher compared to control animals.
\end{abstract}

Key Words: Urea Molasses Block, Goat, Body Weight Gain

\begin{abstract}
ABSTRAK
Pemberian pakan tambahan pada kambing berguna untuk mengoptimalkan potensi ternak dalam berproduksi. Penelitian ini bertujuan untuk mengetahui produktivitas kambing jantan dan betina berupa pertambahan bobot badan harian $(\mathrm{PBBH})$ yang diberikan pakan tambahan urea molasses block (UMB). Penelitian dilaksanakan di Desa Tembeling, Kabupaten Bintan, Provinsi Kepulauan Riau. Ternak yang digunakan milik petani kooperator sebanyak 30 ekor kambing betina (umur sekitar 8-10 bulan) dan enam ekor kambing jantan (umur \pm 10 bulan). Perlakuan yang diuji terdiri atas tiga jenis, yaitu perlakuan $\mathrm{A}=$ pakan tambahan UMB I, perlakuan $\mathrm{B}=$ pakan tambahan UMB II dan perlakuan $\mathrm{C}=$ Kontrol (tidak mendapat pakan tambahan UMB). Data dianalisis dengan mempergunakan analisis varian (ANOVA). Hasil penelitian menunjukkan bahwa perlakuan A secara nyata memberikan $\mathrm{PBBH}$ lebih tinggi $(\mathrm{P}<0,05)$ yaitu 35,9 g/ekor/hari pada kambing betina dibandingkan perlakuan $\mathrm{C}$ yang menghasilkan $\mathrm{PBBH} 32,1$ g/ekor/hari. Pada kambing jantan, PBBH yang didapat secara statistik tidak berbeda nyata antar perlakuan, dengan kisaran 35,4-38,4 g/ekor/hari. Secara umum, hasil pengamatan menunjukkan terdapat pertambahan bobot badan yang lebih tinggi pada ternak kambing betina dengan pemberian pakan tambahan UMB I dibandingkan dengan kontrol.
\end{abstract}

Kata Kunci: Urea Molasses Block, Kambing, Pertambahan Bobot Badan

\section{PENDAHULUAN}

Usaha tani ternak kambing di Provinsi Kepulauan Riau sebagian besar bersifat tradisional. Saat ini tercatat populasi ternak kambing 20.941 ekor. Jumlah ini mengalami penurunan sebesar 2,9\% dibanding dengan tahun sebelumnya yaitu 21.558 ekor. 
Sementara populasi ternak kambing di Kabupaten Bintan, sebagai salah satu kabupaten yang diharapkan sebagai wilayah pengembangan ternak kambing di provinsi ini tercatat hanya berjumlah 1.129 ekor (BPS Kepri 2015).

Produtivitas ternak kambing sangat dipengaruhi oleh faktor pakan. Kualitas dan kuantitas pakan yang sesuai dengan kebutuhan dan fisiologis ternak akan berdampak pada produktivitas yang tinggi. Usaha tani ternak kambing yang tersebar di seluruh wilayah Indonesia hampir seluruhnya berupa usaha peternakan rakyat yang bersifat tradisional, yang salah satunya ditandai dengan pemberian pakan untuk ternak kambing hanya mengandalkan rumput alam yang ketersediaannya tergantung musim dan kandungan nutrisinya rendah. Menurut Haryanto (2009), ketersediaan pakan yang berfluktuasi dan tidak mencukupi kebutuhan gizi ternak untuk mengekspresikan potensi genetiknya secara maksimal, menyebabkan produktivitas ternak rendah. Vanroose et al. (2000) menambahkan bahwa kematian embrio pada ternak kemungkinan dapat disebabkan oleh faktor non infeksi seperti kekurangan nutrien.

Pakan urea molasses block (UMB) merupakan suplemen untuk ternak ruminansia, berbentuk padat yang kaya dengan zat-zat makanan, terbuat dari bahan utama molases (tetes tebu) sebagai sumber energi dan urea sebagai sumber nitrogen (protein). Molases sebagai hasil samping industri gula tebu masih mengandung 50-60\% gula, sejumlah asam amino dan mineral (Hernaman et al. 2005). Selanjutnya Wiratama (2010), menambahkan bahwa urea dalam UMB sebagai penyuplai unsur nitrogen bermanfaat dalam mensintesis protein.

Berdasarkan permasalahan di atas dilakukan penelitian pemberian pakan tambahan UMB pada ternak kambing dan pengaruhnya terhadap produktivitas ternak kambing lokal di Desa Tembeling, Kabupaten Bintan Provinsi Kepulauan Riau.

\section{MATERI DAN METODE}

\section{Waktu dan tempat}

Kegiatan lapang dilaksanakan selama empat bulan yaitu Juni-September 2015. Lokasi kegiatan adalah peternakan kambing Kelompok Peternak Cahaya Purnama, Desa Tembeling, Kampung Siantan, Kecamatan Teluk Bintan, Kabupaten Bintan, Provinsi Kepulauan Riau (Kepri).

\section{Pelaksanaan}

Ternak yang digunakan pada kegiatan ini adalah kambing milik petani kooperator. Jumlah ternak yang digunakan 30 ekor betina (umur sekitar 8-10 bulan) dan 6 ekor jantan (umur \pm 10 bulan). Bahan yang digunakan antara lain bahan penyusun UMB yaitu urea, molases, dedak, konsentrat, mineral, garam, dolomit dan semen. Peralatan yang digunakan adalah timbangan ternak, tempat pakan dan air minum, sekop, ember dan lain-lain. Pada Tabel 1 disajikan komponen teknologi dari masing-masing perlakuan yang dilaksanakan pada penelitian ini.

Jumlah ternak untuk masing-masing perlakuan adalah 10 ekor kambing betina dan 2 ekor pejantan. Pakan UMB dibedakan atas dua jenis, yaitu UMB I dan UMB II, dengan perbedaan bahan penyusunnya. Adapun perbedaan komposisi dari UMB I dan UMB II disajikan pada Tabel 2. 
Tabel 1. Teknologi pakan UMB yang dilaksanakan di Kabupaten Bintan

\begin{tabular}{lccc}
\hline \hline \multirow{2}{*}{ Komponen teknologi } & \multicolumn{3}{c}{ Perlakuan } \\
\cline { 2 - 4 } & (A) & (B) & Eksisting/kontrol (C) \\
\hline Sistem perkandangan & Panggung & Panggung & Panggung \\
Pakan hijauan & Rumput alam & Rumput alam & Rumput alam \\
Urea molasses block & UMB I & UMB II & - \\
Obat cacing & Diberikan & Diberikan & Diberikan \\
\hline
\end{tabular}

Tabel 2. Komposisi bahan penyusun urea molasses block (UMB)

\begin{tabular}{lcc}
\hline \hline Bahan & A (UMB I) (\%) & B (UMB II) (\%) \\
\hline Dedak padi & 30,0 & 60,0 \\
Konsentrat & 30,0 & - \\
Molases & 30,0 & 30,0 \\
Urea & 0,5 & 0,5 \\
Dolomite & 1,5 & 1,5 \\
Mineral & 2,5 & 2,5 \\
Garam & 2,5 & 2,5 \\
Semen & 1,5 & 1,5 \\
Probiotik & 1,5 & 1,5 \\
\hline Jumlah $(\%)$ & 100,0 & 100,0 \\
\hline
\end{tabular}

Urea molasses block yang telah dicetak dan dikeringkan, ditempatkan di dalam kandang ternak. Data yang dikumpulkan berupa: penimbangan bobot badan ternak kambing pada awal dan akhir kegiatan. Data yang didapat selanjutnya ditabulasikan dan dianalisis secara statistik menggunakan analisis varian untuk mengetahui pengaruh dari penerapan paket teknologi terhadap ternak (Steel \& Torrie 2001).

\section{HASIL DAN PEMBAHASAN}

Kegiatan beternak kambing cukup diminati oleh masyarakat Desa Tembeling, di mana berdasarkan informasi petugas penyuluh lapangan (PPL) setempat, jumlah total ternak kambing yang dipelihara oleh peternak setempat lebih kurang 100 ekor. Akan tetapi pemeliharaan ternak kambing masih tradisional. Meskipun ternak kambing telah dikandangkan dengan model kandang panggung, manajemen pakan untuk ternak hanya mengandalkan rumput alam yang diperoleh di tepi jalan maupun di sekitar perkebunan karet. Hampir $100 \%$ peternak tidak pernah memberikan pakan tambahan ataupun hijauan pakan unggul pada ternaknya. Sebagian besar mereka tidak mengetahui perlunya pemberian pakan berkualitas.

Jenis kambing yang dipelihara sebagian besar adalah kambing Kacang dan terdapat juga sedikit campuran dengan kambing Peranakan Ettawah (PE), yang ditandai dengan telinga yang agak berjuntai. Keragaan ternak kambing pada saat penimbangan bobot badan awal kegiatan ditampilkan pada Tabel 3. 
Tabel 3. Hasil penimbangan awal bobot badan kambing (kg) di Kelompok Ternak Cahaya Purnama

\begin{tabular}{lcc}
\hline \hline Perlakuan & $\begin{array}{c}\text { Rata-rata bobot awal } \\
\text { kambing betina }(\mathrm{n}=10)\end{array}$ & $\begin{array}{c}\text { Rata-rata bobot awal } \\
\text { kambing jantan }(\mathrm{n}=2)\end{array}$ \\
\hline A & $20 \pm 1,33$ & $27 \pm 3,0$ \\
B & $22 \pm 1,94$ & $25 \pm 6,0$ \\
C & $21 \pm 2,62$ & $25 \pm 5,0$ \\
\hline
\end{tabular}

A: Pakan tambahan UMB I; B: Pakan tambahan UMB II; C: Kontrol (tidak mendapat pakan tambahan)

Hasil penimbangan bobot badan ternak kambing di awal kegiatan menunjukkan rerata kisaran bobot awal kambing betina adalah 20-22 kg. Sementara pada ternak kambing jantan adalah $25-27 \mathrm{~kg}$. Bobot awal tersebut tidak jauh berbeda seperti yang dilaporkan oleh Pamungkas et al. (2009), yaitu bobot badan kambing Kacang betina adalah $22 \mathrm{~kg}$ dan kambing Kacang jantan adalah $25 \mathrm{~kg}$.

Pengenalan UMB sebagai pakan tambahan untuk ternak kambing memerlukan masa adaptasi yang cukup lama yaitu hampir 2 bulan. Hal ini disebabkan ternak kambing tidak pernah mendapatkan pakan lain selain rumput alam sehingga pakan tambahan merupakan pakan asing bagi ternak. Tingkat konsumsi UMB pada masa adaptasi sangat rendah, bahkan beberapa kambing tidak mau mengonsumsinya. Saat itu ternak kambing hanya mengonsumsi rumput alam. Akan tetapi seiring waktu peternak terus berupaya agar kambing mengonsumsi UMB hingga akhirnya UMB tersebut disukai kambing.

\section{Tampilan produksi ternak kambing}

Pemberian pakan tambahan pada ternak kambing bertujuan untuk mengoptimalkan potensi ternak dalam berproduksi. Jika tanpa pemberian pakan tambahan bernutrisi yang mencukupi kebutuhan ternak dan hanya mengandalkan rumput alam, diperkiraan dapat menghambat produktivitas ternak. Bahan pakan ternak haruslah mengandung nutrien seperti karbohidrat, protein, lemak, mineral dan vitamin sesuai kebutuhannya. Pemberian pakan tambahan berupa UMB pada ternak kambing dalam kegiatan ini adalah satu buah UMB dengan berat 200 g/ekor, yang diletakkan di tempat pakan. Rata-rata satu buah UMB yang diberikan tersebut dihabiskan ternak selama empat hari.

Tabel 4. Keragaan perubahan bobot badan kambing betina dara selama 120 hari pemeliharaan

\begin{tabular}{lccc}
\hline \multirow{2}{*}{ Parameter } & \multicolumn{3}{c}{ Perlakuan } \\
\cline { 2 - 4 } & $\mathrm{A}$ & $\mathrm{B}$ & $\mathrm{C}$ \\
\hline Bobot awal $(\mathrm{kg})$ & 20,00 & 22,05 & 21,05 \\
Bobot akhir $(\mathrm{kg})$ & 24,31 & 26,20 & 24,90 \\
PBB $(\mathrm{kg})$ & 4,31 & 4,15 & 3,85 \\
PBBH g/ekor/hari & $35,90^{\mathrm{a}}$ & $34,60^{\mathrm{ab}}$ & $32,10^{\mathrm{b}}$ \\
\hline
\end{tabular}

PBB: Pertambahan bobot badan; PBBH: Pertambahan bobot badan harian

Pada Tabel 4 terlihat bahwa terdapat perbedaan pertambahan bobot badan harian $(\mathrm{PBBH})$ ternak kambing betina dara antar perlakuan A, B dan C. Perlakuan A yaitu pemberian pakan tambahan UMB I secara statistik memberikan PBBH lebih tinggi $(\mathrm{P}<0,05)$ yaitu 35,9 g/ekor/hari dibandingkan dengan perlakuan $\mathrm{C}$ (kontrol/tanpa UMB) yang menghasilkan PBBH 32,1 g/ekor/hari. Artinya ada pertambahan bobot badan pada 
ternak kambing dengan pemberian pakan tambahan UMB I. Sementara perlakuan B (pemberian pakan tambahan UMB II) menghasilkan PBBH 34,6 g/ekor pada kambing betina, secara statistik tidak berbeda $(\mathrm{P}>0,05)$ dengan perlakuan A maupun $\mathrm{C}$. Pada kambing jantan, hasil analisis menunjukkan bahwa PBBH secara statistik tidak terdapat perbedaan di antara ketiga perlakuan tersebut $(\mathrm{P}>0.05)$ (Tabel 5).

Tabel 5. Keragaan perubahan bobot badan kambing jantan selama 120 hari pemeliharaan

\begin{tabular}{lrrr}
\hline \hline \multirow{2}{*}{ Parameter } & \multicolumn{3}{c}{ Perlakuan } \\
\cline { 2 - 4 } & $\mathrm{A}$ & $\mathrm{B}$ & $\mathrm{C}$ \\
\hline Bobot awal (kg) & 27,00 & 25,00 & 25,00 \\
Bobot akhir (kg) & 31,60 & 29,50 & 29,30 \\
PBB (kg) & 4,61 & 4,46 & 4,25 \\
PBBH (g/ekor/hari) & 38,40 & 37,20 & 35,40 \\
\hline
\end{tabular}

PBB: Pertambahan bobot badan; PBBH: Pertambahan bobot badan harian

Pertambahan bobot badan harian $(\mathrm{PBBH})$ ternak kambing betina dan jantan yang mendapat pakan UMB pada kegiatan ini lebih tinggi 8-12\% dibandingkan dengan tanpa pemberian UMB. Hal ini menunjukkan bahwa pemberian pakan UMB untuk kambing dapat memenuhi kebutuhan nutrisi dari ternak tersebut, yang berpengaruh pada peningkatan $\mathrm{PBBH}$ ternak tersebut, meskipun pertambahan bobot badan ternak kambing dalam kegiatan ini dapat dikategorikan belum optimal, karena pakan tambahan yang diberikan pada ternak kambing dalam bentuk UMB membutuhkan waktu rata-rata empat hari untuk dikonsumsi seluruhnya oleh ternak. Padahal dalam penyusunan bahan UMB telah diperhitungkan untuk pertambahan bobot badan harian yang optimal ternak kambing harus mengonsumsi satu buah UMB dalam waktu dua hari, dengan asumsi berat satu buah UMB 200 g, rata-rata ternak kambing mengonsumsi 100 g/ekor/hari. Menurut Hatmono \& Indriyadi (1997), dosis pemberian UMB 120 g/ekor/hari untuk ternak kecil (kambing dan domba). Rendahnya konsumsi UMB dalam kegiatan ini disebabkan karena ternak kambing belum terbiasa mengonsumsi pakan tambahan. Hasil penelitian yang dilaporkan oleh Zurriyati et al. (2004), terjadi peningkatan PBBH ternak kambing Kacang dengan pemberian pakan tambahan berupa dedak padi dan konsentrat sebesar 50,56 g/ekor/hari. Hatungimana \& Ndolisha (2015), melaporkan PBBH domba Merino yang diberi pakan UMB berkisar 40-54 g/ekor/hari. Sementara hasil penelitian ini hampir sama dengan yang dilaporkan Farizal (2008), yaitu mendapatkan PBBH domba jantan lepas sapih yang diberikan pakan tambahan UMB sebesar 30,58 g/ekor/hari.

\section{KESIMPULAN}

Pemberian pakan tambahan dalam bentuk UMB I menghasilkan PBBH pada ternak kambing betina dara lebih tinggi 8-12\% dibandingkan dengan tanpa pemberian UMB di Desa Tembeling, Kabupaten Bintan, Provinsi Kepulauan Riau, sedangkan pada kambing jantan tidak berpengaruh.

\section{DAFTAR PUSTAKA}

BPS Provinsi Kepulauan Riau. 2015. Kepulauan Riau dalam angka 2015. Tanjungpinang (Indonesia): Badan Pusat Statistik Kepulauan Riau. 
Farizal. 2008. Respon pemberian urea molasses block (UMB) dan hay rumput kumpai (Hymenaehne amplexicaulis) terhadap pertambahan bobot badan domba lokal jantan. J Ilmiah Ilmu-Ilmu Peternakan. XI:24-27.

Haryanto B. 2009. Inovasi teknologi pakan ternak dalam sistem integrasi tanaman-ternak bebas limbah mendukung upaya peningkatan produksi daging. Pengembangan Inovasi Pertanian. 2:163-176.

Hatungimana E, Ndolisha P. 2015. Effect of urea molasse block supplementation on growth performance of sheep. J Novel Res Life Sci. 2:38-43.

Hatmono H, Indriyadi H. 1997. Urea molases blok pakan suplemen untuk ternak ruminansia. Ungaran (Indonesia): PT Trubus Agriwidya.

Hernaman I, Hidayat R, Mansyur. 2005. Pengaruh penggunaan molases dalam pembuatan silase campuran ampas tahu dan pucuk tebu kering terhadap nilai $\mathrm{pH}$ dan komposisi zat-zat makanannya. J Ilmu Ternak. 5:94-99.

Pamungkas FA, Batubara A, Doloksaribu M, Sihite E. 2009. Petunjuk teknis potensi plasma nutfah kambing lokal di Indonesia. Bogor (Indonesia): Pusat Penelitian dan Pengembangan Peternakan.

Steel GD, Torrie JH. 2001. Principles and procedure of statistics. A biometrical approach. New York (USA): Mc Graw-Hill Inc.

Wiratama MA. 2010. Pengaruh penggunaan fermented mother liquour dalam urea molasses block terhadap kecernaan nutrien ransum sapi Peranakan Friesien Holstein dara [Skripsi]. Surakarta (Indonesia): Universitas Sebelas Maret.

Vanroose G, de Kruif A, Soom AV. 2000. Embryonic mortality and emryo-pathogen interactions. J Anim Reprod Sci. 60:131-143.

Zurriyati Y, Batubara A, Syam A. 2004. Kajian integrasi ternak kambing dengan perkebunan karet di Provinsi Riau. Dalam: Haryanto B, Mathius IW, Prawiradiputra BR, Lubis D, Priyanti A, Djajanegara A, penyunting. IPTEK sebagai Motor Penggerak Pembangunan Sistem dan Usaha Agribisnis Peternakan. Prosiding Seminar Nasional Sistem Integrasi Tanaman-Ternak. Denpasar, 20-22 Juli 2004. Bogor (Indonesia): Puslitbangnak bekerjasama dengan Balai Pengkajian Teknologi Pertanian (BPTP) Bali dan Crop Animal System Research Network (CASREN). hlm. 482-490.

\section{DISKUSI}

\section{Pertanyaan}

Jenis pakan apa saja yang diberikan pada ternak. Apakah ada perbedaan keuntungan antara kambing yang diberikan UMB dengan yang tidak diberikan UMB.

\section{Jawaban}

Pakan yang diberikan rumput alam dengan kandungan protein kasar 11\%. Dari hasil analisis ekonomi masih lebih menguntungkan yang diberi UMB. 